JOURNAL OF APPLIED MECHANICAL
ENGINEERING AND RENEWABLE
ISAS Vol. 1 No. 1, Februari $2021.24-29$

\title{
Analisis Jumlah Tenaga Kerja Optimal Dengan Metode Work Load Analysis (WLA) di PT. RSI
}

\author{
Darsini $^{1}$, Andika Maulana ${ }^{2}$, Budi Wibowo ${ }^{3}$ \\ 1,2,3 Teknik Industri, Fakultas Teknik, Universitas Veteran Bangun Nusantara Sukoharjo \\ 1'dearsiny@yahoo.com*,2Andikaprc0708@gmail.com
}

\begin{abstract}
Workload of employees at PT. RSI in the pressing department is still low, because in the pressing section the division of work for each employee is not optimal or evenly distributed. So it is necessary to do research with the title Analysis of the Optimal Workforce at PT. RSI. The method used for testing the optimal amount of load is the Work Load Analysis (WLA) method, which aims to calculate the optimal workload and number of workers at PT. RSI. The sample in this study were 15 employees in the pressing department which were divided into 4 sections, where section 1 had 4 employees, section 2 had 4 employees, section 3 had 4 employees, and section 4 contained 3 employees. The results of this study indicate that the workload before the research in section 1 was $52 \%$ to $70 \%$, part 2 from $51 \%$ to $68 \%$, part 3 from $56 \%$ to $75 \%$, and part 4 still $71 \%$ because there was no reduction in labor, because the workload in section 4 is optimal. So the optimal number of workers in the pressing department is 3 employees in section 1, 3 employees in section 2, 3 employees, and 4 still 3 employees.
\end{abstract}

Keywords: Total Workforce, Optimal, Work Load Analysis (WLA)

\begin{abstract}
Abstrak
Beban kerja karyawan di PT. RSI di departemen pressing masih rendah, dikarenakan pada bagian pressing pembagian kerja pada masing-masing karyawan belum optimal atau merata. Maka perlu dilakukan penelitian dengan judul Analisis Jumlah Tenaga Kerja Optimal di PT. RSI. Metode yang digunakan untuk pengujian jumlah beban yang optimal dengan metode Work Load Analysis (WLA), yang tujuannya untuk menghitung beban kerja dan jumlah tenaga kerja optimal di PT. RSI. Sampel dalam penelitian ini adalah 15 karyawan di departemen pressing yang dibagi menjadi 4 bagian, dimana bagian 1 terdapat 4 karyawan, bagian 2 terdapat 4 karyawan, bagian 3 terdapat 4 karyawan, dan bagian 4 terdapat 3 karyawan. Hasil penelitian ini menunjukan bahwa beban kerja sebelum dilakukan penelitian pada bagian 1 sebesar 52\% menjadi 70\%, bagian 2 dari $51 \%$ menjadi $68 \%$, bagian 3 dari $56 \%$ menjadi $75 \%$, dan bagian 4 masih tetap $71 \%$ karena tidak dilakukan pengurangan tenaga kerja, diakibatkan beban kerja di bagian 4 sudah optimal. Jadi jumlah tenaga kerja yang optimal di departemen pressing adalah pada bagian 1 berjumlah 3 karyawan, bagian 2 berjumlah 3 karyawan, bagian 3 berjumlah 3 karyawan, dan bagian 4 tetap berjumlah 3 karyawan.
\end{abstract}

Kata Kunci: Jumlah Tenaga Kerja, Optimal, Work Load Analysis (WLA)

\section{Pendahuluan}

Salah satu metode perencanaan kebutuhan tenaga Sumber daya manusia dalam hal ini karyawan yang adalah work load analysis yaitu deskriptif dari beban berkinerja tinggi, berperan dominan dalam menjalankan kerja yang dibutuhkan dalam suatu unit perusahaan. operasional perusahaan atau pencapaian tujuan yang Metode ini akan memberikan informasi mengenai telah ditetapkan. Sebuah organisasi atau perusahaan, pengalokasian sumber daya karyawan untuk sumber daya manusia /karyawan adalah kekuatan utama menyelesaikan beban kerja. Metode ini merupakan perusahaan yang memberikan perhatian khusus pada proses untuk menghitung beban kerja suatu fungsi efisiensi, efektivitas, dan produktivitas. Karena dari tertentu dalam perusahaan. Dari perhitungan ini ketiga hal tersebut, perusahaan dapat melihat kemudian dapat ditentukan berapa jumlah kebutuhan penggunaan optimal dari sumber daya yang dimiliki ideal pegawai yang dibutuhkan [1].

serta pencapaiannya terhadap target yang diinginkan Melakukan perencanaan kebutuhan tenaga kerja oleh suatu perusahaan. Salah satu faktor yang yang optimal harus memperhatikan beberapa komponen berpengaruh agar pesanan dapat diselesaikan atau yang ada di perusahaan karena komponen ini terpenuhi sesuai dengan jadwal yang ditetapkan yaitu diggunakan dalam menentukan jumlah tenaga kerja. faktor tenaga kerja. 
Perencanaan atau penentuan jumlah tenaga kerja dapat berjalan sesuai dengan harapan [2].

Suatu organisasi perlu menetapkan identifikasi atau uraian suatu pekerjaan dan pengetahuan dan keterampilan yang dibutuhkan untuk melakukan karyawan ditetatpkan untuk melaksanakan suatu operator yang diperlukan dalam departemen tersebut. pekerjaan tertentu. Penetapan uraian dan pengetahuan Metode Work Load Analysis (WLA) adalah analisis serta keterampilan suatu pekerjaan akan memberikan beban kerja yang mengidentifikasi baik jumlah kejelasan dalam hal proses pelaksanaan pekerjaan dan karyawan maupun kwalifikasi karyawan yang juga bermanfaat dalam penentuan jumlah karyawan [3]. diperlukan untuk mencapai tujuan organsasi [8]. Dengan Menurut Lestari [4] analisis pekerjaan adalah prosedur diterapkannya metode Work Load Analysis (WLA) yang dilalui untuk menentukan tanggung jawab posisi- diharapkan dapat terjadi peningkatan efisiensi kerja posisi tersebut, dan karakteristik orang-orang yang karyawan pada umumnya, sehingga bisa memenuhi bekerja untuk posisi tersebut. Analisis pekerjaan target perusahaan.

memberikan pekerjaan memberikan informasi yang digunakan untuk membuat deskripsi pekerjaan (daftar tentang pekerjaan) dan spesifikasi pekerjaan (jenis orang yang harus dipekerjakan untuk pekerjaan tersebut).

Menurut Sabrini, dkk [5]. Untuk menentukan beban kerja pada beberapa kategori atau tingkatan, yaitu: rendah dengan skala interval 0-40, sedang dengan skala interval 41-60, dan tinggi dengan skala interval 61-100. Analisis beban kerja (ABK) adalah proses mengumpulkan, menghitung, dan menetapkan volume usaha/beban kerja (jam kerja orang/man-hour) pada saat itu (apa adanya) untuk menyelesaikan pekerjaan di unit kerja/divisi/departemen tertentu [6]. Analisis beban kerja diperlukan pada beberapa kondisi berikut :

a. Munculnya tantangan organisasi untuk melakukan perubahan dalam struktur organisasi.

b. Munculnya indikasi keborosan atau beban kerja yang terlalu besar untuk diselesaikan dalam sebuah unit kerja/divisi/departemen.

c. Proses merancang sebuah unit kerja yang baru untuk memperoleh estimasi jumlah tenaga kerja yang dibutuhkan.

Beban kerja dipengaruhi oleh 2 faktor, yaitu: faktor eksternal dan faktor internal. Menurut Manuaba [7], faktor-faktor yang mempengaruhi beban kerja antara lain:

a. Faktor eksternal, yaitu beban yang berasal dari luar tubuh pekerja, seperti :

1. Tugas-tugas yang bersifat bersifat fisik, seperti stasiun kerja, tata ruang, tempat kerja, alat dan sarana kerja, kondisi kerja, sikap kerja, dan tugas-tugas yang bersifat psikologis, seperti kompleksitas pekerjaan, tingkat kesulitan, b. tanggung jawab pekerjaan.

2. Organisasi kerja, seperti lamanya waktu bahwa yang telah dikumpulkan dan disajikan dalam bekerja, waktu istirahat, shift kerja, kerja populasi data tersebut cukup secara objektif. Menurut malam, sistem pengupahan, model struktur Arif [10] Pengujian ini dilakukan untuk mengetahui organisasi, pelimpahan tugas dan wewenang. apakah data yang didapat telah seragam dan tidak

3. Lingkungan kerja adalah lingkungan kerja melebihi dari batas kontrol atas (BKA) dan batas kontrol fisik, lingkungan kimiawi, lingkungan kerja bawah (BKB) yang telah ditentukan. Bila dari biologis dan lingkungan kerja psikologis. keseragaman data terdapat data yang tidak seragam

b. Faktor internal adalah faktor yang berasal dari maka data tersebut dibuang. Rumus untuk menentukan dalam tubuh itu sendiri akibat dari reaksi beban kecukupan data:

kerja eksternal. Faktor internal meliputi faktor

\section{Metode Penelitian}

Penelitian dilakukan di PT. RSI, perusahaan ini Penelitian ini dilakukan pada bagian pressing dengan karyawan sebanyak 15 orang. Dalam melakukan penelitian yang dilakukan dari awal data diperoleh sebagai berikut:

a. Uji Keseragaman Data

berasal dari sistem yang sama, maka dilakukan pengujian terhadap keseragaman data. Untuk itu pengujian keseragaman data guna kan data yang memiliki karakteristik yang pengambilan data. Menurut Nugroho, dkk. [9], uji kecukupan data dilakukan untuk mengetahui banyaknya pengamatan yang harus dilakukan dalam Work Sampling hasil uji kecukupan data.

Rumus untuk menentukan keseragaman data:

$$
(\bar{X})=\frac{\sum X i}{k}
$$

- Standar deviasi

$$
(\sigma \mathrm{x})=\sqrt{\frac{\sum(X i-\bar{X})^{2}}{N-1}}
$$

$$
\begin{aligned}
& \mathrm{BKA}=\bar{X}+3 \sigma \mathrm{x} \\
& \mathrm{BKB}=\bar{X}-3 \sigma \mathrm{x}
\end{aligned}
$$

Uji Kecukupan Data

Uji kecukupan data diperlukan untuk memastikan memproduksi garmen, yang berupa kaos jersey printing. stopwatch sebanyak 10 kali atau $\mathrm{N}=10$. Berikut proses 


$$
\begin{aligned}
N^{\prime} & =\left[\frac{k / s \sqrt{N\left(\sum X i^{2}\right)-\left(\sum X\right)^{2}}}{\sum X}\right]^{2} \\
& =\left[\frac{2 / 0,05 \sqrt{10(394834)-(3994196)}}{1986}\right]^{2}
\end{aligned}
$$

c. Waktu Normal (Wn)

Waktu normal untuk suatu elemen operasi kerja adalah semata-mata menunjukkan bahwa seorang operator yang berkualifikasi baik akan pekerja menyelesaikan pekerjaan pada tempo kerja yang normal [11]. Rumus untuk menghitung waktu normal adalah:

$$
\mathrm{Wn}=\mathrm{Ws} \times \mathrm{P}
$$

\section{d. Waktu Baku}

Penentuan waktu baku untuk menentukan target produksi ini dilakukan dengan cara pengukuran langsung dengan menggunakan jam henti. Pengukuran dilakukan dikarenakan didalam melakukan pekerjaan dipengaruhi oleh beberapa faktor yang tidak dapat dihindari baik faktor dari dalam maupun dari luar perusahaan [11]. Waktu baku didapatkan dengan rumus:

$$
W b=W n+\frac{100}{100-\text { Allowance }}
$$

\section{Sampling Kerja}

Work Sampling adalah suatu teknik untuk mengadakan sejumlah besar pengamatan terhadap aktifitas kinerja dari mesin, proses atau pekerja/operator [11]. Perbedaan metode jam henti dengan sampling pekerjaan adalah pada cara sampling pekerjaan pengamat tidak terus menerus berada ditempat pekerjaan melainkan mengamati hanya pada sesaat-sesaat pada waktu-waktu tertentu yang ditentukan secara acak [9]. Metode sampling kerja sangat cocok untuk digunakan dalam melakukan pengamatan atas pekerjaan yang sifatnya tidak berulang dan memiliki siklus waktu yang relatif panjang.

\section{Metode analisis beban kerja}

Metode Work Load Analysis (WLA) dilakukan untuk mengetahui tingkat efisiensi kerja berdasarkan total prosentase beban kerja dari job yang diberikan dalam menyelesaikan pekerjaannya. Dan dapat menentukan jumlah karyawan yang sebenarnya untuk dipekerjakan dalam bagian Pressing langkahlangkahnya sebagai berikut:

a. Mengetahui struktur organisasi dan job description tiap jabatan

b. Menentukan aktivitas dan waktu penyelesaian aktivitas tiap posisi jabatan. Aktivitas-aktivitas tersebut dikelompokkan pada job description yang dilakukan oleh aktivitas terkait.

c. Melakukan pengamatan untuk menghitung besarnya prosentase waktu pelaksanaan aktivitas dengan waktu yang disediakan oleh perusahaan.

d. Menentukan jumlah menit pengamatan e. Penentuan Allowance

f. Perhitungan besarnya beban kerja dengan menggunakan rumus di bawah ini:

1. Menurut Martono [6] analisis beban kerja adalah proses mengumpulkan, menghitung, dan menetapkan volume usaha/beban kerja (jam kerja orang/man-hour) pada saat itu (apa adanya) untuk menyelesaikan pekerjaan di unit kerja/divisi/departemen tertentu. Dengan menggunakan rumus:

Tenaga Kerja yang diperlukan $=\frac{\text { total beban kerja }}{\text { waktu kerja efektif }}$

2. Sedangkan analisa beban kerja berdasarkan produktivitas perbandingan frekuensi antara aktivitas yang sesuai dan tidak sesuai dengan job desciption yang dilakukan oleh setiap karyawan [10]. Dengan menggunakan rumus:

$$
\text { Beban Kerja }=\frac{\begin{array}{c}
\text { \%produktif } x \text { ranting faktor } x \\
\text { total waktu pengamatan } x \\
(1+\text { allowance })
\end{array}}{\text { Total waktu pengamatan }}
$$

3. Analisis beban kerja (work load analysis)

Analisis beban kerja (work load analysis) menurut Roidelindho [12] bahwa untuk mengukur beban kerja karyawan diformulasikan dengan cara:

$$
\text { Output Baku }=\frac{\text { lama waktu bekerja }}{\text { waktu baku }}
$$

Hasil langsung dari analisis beban kerja adalah penetapan bilangan jumlah karyawan yang diperlukan untuk melaksanakan sejumlah pekerjaan tertentu selama waktu tertentu.

\section{Allowance (Kelonggaran) dan Performance Rating}

Salah satu yang paling penting di perhatikan dalam pengukuran waktu adalah faktor kelonggaran. Faktor kelonggaran ini diambil pada waktu normal yang telah didapatkan. Kelonggaran diberikan untuk tiga hal yaitu: untuk kebutuhan pribadi, menghilangkan rasa lelah, dan hambatan-hambatan yang tidak dapat dihindarkan. Metode Westinghouse dimana akan mengarahkan pada penilaian 4 faktor yang dianggap menentukan kewajaran atau ketidakwajaran dalam bekerja [11].

Tabel 1. Daftar Allowance dengan metode Westhinghouse

\begin{tabular}{llrlrr}
\hline SKILL & & & EFFORT & \\
\hline Superskill & A1 & $+0,15$ & Superskill & A1 & $+0,13$ \\
& A2 & $+0,13$ & & A2 & $+0,12$ \\
Excellent & B1 & $+0,11$ & Excellent & B1 & $+0,10$ \\
& B2 & $+0,08$ & & B2 & $+0,08$ \\
Good & C1 & $+0,06$ & Good & C1 & $+0,05$ \\
& C2 & $+0,03$ & & C2 & $+0,02$ \\
Average & D & 0,00 & Average & D & 0,00 \\
Fair & E1 & $-0,05$ & Fair & E1 & $-0,04$ \\
& E2 & $-0,10$ & & E2 & $-0,08$ \\
Poor & F1 & $-0,16$ & Poor & F1 & $-0,12$ \\
& F2 & $-0,22$ & & F2 & $-0,17$ \\
\hline
\end{tabular}




\begin{tabular}{lrrlrr}
\hline CONDITION & \multicolumn{4}{l}{ CONSISTENCY } \\
\hline Ideal & $\mathrm{A}$ & $+0,06$ & Ideal & $\mathrm{A}$ & $+0,04$ \\
Excellent & $\mathrm{B}$ & $+0,04$ & Excellent & $\mathrm{B}$ & $+0,03$ \\
Good & $\mathrm{C}$ & $+0,02$ & Good & $\mathrm{C}$ & $+0,01$ \\
Average & $\mathrm{D}$ & 0,00 & Average & $\mathrm{D}$ & 0,00 \\
Fair & $\mathrm{E}$ & $-0,03$ & Fair & $\mathrm{E}$ & $-0,02$ \\
Poor & $\mathrm{F}$ & $-0,07$ & Poor & $\mathrm{F}$ & $-0,04$ \\
\hline
\end{tabular}

\begin{tabular}{|c|c|c|c|c|}
\hline \multirow[t]{2}{*}{ No } & \multicolumn{4}{|c|}{ Waktu (Detik) } \\
\hline & Bagian 1 & Bagian 2 & Bagian 3 & Bagian 4 \\
\hline 1 & 209 & 206 & 204 & 200 \\
\hline 2 & 203 & 193 & 195 & 203 \\
\hline 3 & 204 & 203 & 195 & 200 \\
\hline 4 & 208 & 192 & 203 & 205 \\
\hline 5 & 203 & 192 & 203 & 203 \\
\hline 6 & 197 & 204 & 196 & 197 \\
\hline 7 & 192 & 206 & 196 & 197 \\
\hline 8 & 198 & 203 & 204 & 205 \\
\hline 9 & 195 & 192 & 195 & 205 \\
\hline 10 & 204 & 200 & 204 & 197 \\
\hline Jumlah & 2013 & 1991 & 1995 & 2012 \\
\hline$\sum x i^{2}$ & $4,052,169$ & $3,964,081$ & $3,980,025$ & $4,028,049$ \\
\hline$\sum \bar{x} i$ & 201,3 & 199,1 & 199,5 & 201,2 \\
\hline
\end{tabular}

Adapun alur penelitiannya digambarkan seperti alur penelitian berikut ini:

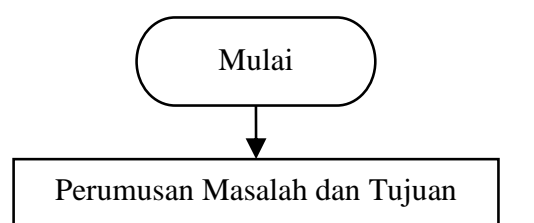

PT. RSI terdapat departemen pressing yang mempunyai 4 bagian. Pada bagian 1, 2, dan 3 masingmasing terdapat 4 karyawan, dan bagian 4 terdapat 3 karyawan. Pengambilan datanya dilakukan dengan stopwatch yang dilakukan sebanyak 10 kali pengamatan pada tiap-tiap bagian. Hal ini untuk mengetahui waktu kerja dalam menghasilkan 1 produk (pcs). Rata-rata $\left(\sum x i\right)$ diperoleh dari jumlah waktu kerja dibagi waktu pengamatan (10) di masing-masing bagian. Setelah diketahui jumlah, rata-rata, serta nilai kuadrat dari yang sudah diamati dilakukan uji keseragaman data untuk mengetahui apakah ada data yang melewati batas kendali atas dan batas kendali bawah.

Nilai Performance Rating dan Allowance masingmasing aktifitas karyawan maka dapat dihitung output baku, jumlah tenaga kerja optimal, dan beban kerja dengan menggunakan rumus sebagai berikut untuk bagian 1

$$
\begin{aligned}
\text { Output Baku } & =\frac{\text { lama waktu bekerja }}{\text { waktu baku }} \\
& =\frac{25.200}{212,48} \\
& =118.59 \approx 199 \mathrm{pcs}
\end{aligned}
$$

Dalam 1 hari bekerja karyawan di PT. RSI pada bagian 1 menghasilkan produk sebesar 119 pcs. Selanjutnya dapat dihitung jumlah tenaga kerja optimal.

Jumlah Tenaga Kerja Optimal ( $n$ )

$$
=\frac{\text { target produksi }}{\text { output baku }}=\frac{250}{119}=2,10 \approx 3 \text { orang }
$$

Jumlah tenaga kerja yang optimal pada bagian 1 adalah 3 orang karyawan dari 4 karyawan sebelumnya. Setelah itu dapat diketahui beban kerja karyawan dibawah ini:

$$
\begin{aligned}
& \text { Beban Kerja Sebelum }=\frac{\text { target produksi }}{\text { Jumlah Tenaga kerja }} \\
&=\frac{250}{4} \\
&=62,5 \text { pcs } / \text { orang } \\
& \begin{aligned}
\% \text { Beban Kerja Sebelum } & =\frac{\text { beban } \text { kerja }}{\text { output baku }} \times 100 \% \\
& =\frac{62.5}{119} \times 100 \%=52 \%
\end{aligned}
\end{aligned}
$$

Data rata-rata pengukuran waktu kerja seperti tabel berikut. 


$$
\begin{aligned}
\text { Beban Kerja Sesudah }= & \frac{\text { target produksi }}{\text { jumlah tenaga kerja }} \\
= & \frac{250 \text { pcs }}{3 \text { orang }}=83,3 \text { pcs } / \text { orang } \\
\% \text { Beban Kerja Sesudah } & =\frac{\text { beban } \text { kerja }}{\text { output baku }} \times 100 \% \\
& =\frac{83,3}{119} \times 100 \%=70 \%
\end{aligned}
$$

Pengurangan tenaga kerja menjadi 3 orang pada bagian ini dapat meningkatkan beban kerja dengan ratarata pada bagian 1 dari $52 \%$ menjadi $70 \%$. Sehingga tidak terjadi kekurangan beban kerja yang menyebabkan kurangnya produktivitas karyawan. Sedangkan untuk bagian 2, 3, dan 4 masing-masing sama dalam menentukan jumlah tenaga kerja optimal, penentuan beban kerja tersebut.

Bagian 2 Pengurangan tenaga kerja menjadi 3 orang pada bagian ini dapat meningkatkan beban kerja dengan rata-rata pada bagian 2 dari $51 \%$ menjadi $68 \%$. Sehingga tidak terjadi kekurangan beban kerja yang menyebabkan kurangnya produktivitas karyawan. Bagian 3 Pengurangan tenaga kerja menjadi 3 orang pada bagian ini dapat meningkatkan beban kerja dengan rata-rata pada bagian 3 dari $56 \%$ menjadi $75 \%$. Sehingga tidak terjadi kekurangan beban kerja yang menyebabkan kurangnya produktivitas karyawan.

Jumlah tenaga kerja pada bagian 4 adalah 3 orang, dengan total beban kerja $71 \%$. Sehingga tidak perlu dilakukan pengurangan jumlah tenaga kerja dikarenakan beban kerja di bagian 4 sudah optimal. Jika dilakukan pengurangan jumlah tenaga kerja maka total beban kerja di bagian ini berlebihan atau terlalu banyak.

Dari hasil analisis proses perhitungan diatas terdapat solusi yang dapat diterapkan pada 3 bagian di departemen pressing ini, yaitu dengan pengurangan tenaga kerja yang bekerja mempressing kain. Hal ini disebabkan karena kurangnya beban kerja karyawan. Kemungkinan pengurangan tenaga kerja pada ketiga bagian ini, dikarenakan beban kerja yang presentasinya jauh dari angka $100 \%$. Pengurangan tenaga kerja karyawan menjadi 12 orang pada departemen ini dapat meningkatkan beban kerja rata-rata sehingga tidak terjadi lagi kekurangan beban kerja pada karyawan yang akan mengurangi produktivitas kerja.

Tabel 3. Data Beban Kerja Karyawan Sebelum dan Sesudah

\begin{tabular}{cccc} 
Bagian & $\begin{array}{c}\text { Tenaga Kerja } \\
\text { (Sebelum) }\end{array}$ & $\begin{array}{c}\text { Presentase } \\
\text { Beban Kerja }\end{array}$ & $\begin{array}{c}\text { Beban Kerja Rata-Rata } \\
\text { (pcs/orang) }\end{array}$ \\
\hline 1 & 4 & $52 \%$ & 62,5 \\
2 & 4 & $51 \%$ & 62,5 \\
3 & 4 & $56 \%$ & 62,5 \\
4 & 3 & $71 \%$ & 83,3 \\
\hline Bagian & Tenaga Kerja & Presentase & Beban Kerja Rata-Rata \\
& (Sesudah) & Beban Kerja & (pcs/orang) \\
\hline 1 & 3 & $70 \%$ & 83,3 \\
2 & 3 & $68 \%$ & 83,3 \\
3 & 3 & $75 \%$ & 83,3 \\
4 & 3 & $71 \%$ & 83,3 \\
\hline
\end{tabular}

Hasil pada tabel beban kerja di atas menunjukkan presentase beban kerja pada ketiga bagian di departemen pressing yang sudah meningkat diatas $61 \%$. Dari uraian hasil analisis tersebut sebagai perusahaan untuk disarankan melakukan pengurangan karyawan pada ketiga bagian di departemen pressing tersebut sebagai upaya peningkatan produktivitas kerja dan peningkatan pelayanan kepada konsumen. Tidak terlepas dari tingginya permintaan konsumen yang berbanding dengan peningkatan pelayanan ke konsumen.

\section{Kesimpulan}

Dari hasil pengamatan yang telah dilaksanakan dapat disimpulkan, bahwa jumlah tenaga kerja yang optimal adalah sebagai berikut: Beban kerja karyawan pada bagian pressing di PT. RSI pada bagian 1 total beban kerja 52\% setelah dilakukan pengurangan karyawan naik dengan total beban kerja sebesar $70 \%$. Bagian 2 total beban kerja sebesar 51\% setelah dilakukan pengurangan karyawan naik dengan total beban kerja sebesar $68 \%$. Bagian 3 total beban kerja sebesar $56 \%$ setelah dilakukan pengurangan karyawan naik dengan total beban kerja sebesar $75 \%$. Dan bagian 4 total beban kerja sebesar $71 \%$ dan tidak dilakukan pengurangan tenaga kerja, dikarenakan beban kerja di bagian ini sudah optimal. Setelah dilakukan perhitungan beban kerja pada departemen pressing, disimpulkan bahwa dapat meningkatkan beban kerja agar tidak terlalu kurangnya beban kerja. Maka dilakukan pengurangan tenaga kerja pada ketiga bagian di departemen pressing. Pada bagian 1 terdapat 4 karyawan dikurangi menjadi 3 karyawan, bagian 2 terdapat 4 karyawan dikurangi menjadi 3 karyawan, dan bagian 3 terdapat 4 karyawan dikurangi menjadi 3 karyawan.

\section{Ucapan Terima Kasih}

Terima kasih disampaikan kepada pimpinan PT. RSI yang telah memfasilitasi sebagai tempat pengambilan data selama penelitian.

\section{Daftar Rujukan}

[1] S. Wardah, "Penentuan Jumlah Karyawan Yang Optimal Pada Penanaman Lahan Kelapa Sawit Dengan Menggunakan Metode Work Load Analysis (WLA)," Jurnal Teknik Industri: Jurnal Hasil Penelitian dan Karya Ilmiah dalam Bidang Teknik Industri, vol. 3, no. 1, 2017, doi: 10.24014/jti.v3i1.6150.

[2] A. Sofjan, Manajemen Produksi dan Operasi. Jakarta: Fakultas Ekonomi, Universitas Indonesia, 2008.

[3] L. E. Anggraeni and R. Prabowo, "Analisis Beban Kerja Untuk Menentukan Jumlah Karyawan Optimal (Studi Kasus PT. Sanjayatama Lestari Sirabaya)," Jurnal Teknik Industri, 2015.

[4] D. Lestari, “Analisis Desain Pekerjaan Pada PT. Ciputra Graga Mitra di Samarinda," eJournal Ilmu Administrasi Bisnis, vol. 4, no. 1, pp. 211-221, 2016.

[5] A. Sabrini, J. Rambe, and D. Wahyuni, "Pengukuran Beban Kerja Karyawan Dengan Menggunakan Metode SWAT (Subjective Workload Assessment Technique) dan Work Sampling di PT. XYZ," Jurnal Teknik Industri USU, vol. 4, no. 2, 2013.

[6] R. V. Martono, Analisis Produktivitas \& Efisiensi. Jakarta: PT. Gramedia Pustaka Utama, 2019. 
[7] Manuaba, Hubungan Beban Kerja dan Kapasitas Kerja. Jakarta: Rineka Cipta, 2000.

[8] Simamora, Manajemen Sumber Daya Manusia. Yogyakarta: YKPN, 1995.

[9] S. Nugroho, S. Djoko, and H. Nuha, "Analisa Beban Kerja Dalam Penentuan Jumlah Tenaga Kerja Optimal Pada Departemen Packing (Studi kasus PT. Arjuna Utama Kimia Surabaya)," Teknik Industri Universitas 17 Agustus 1945 Surabaya, vol. 11, no. 4, 2017.

[10] A. Ridwan, "Analisa Beban Kerja dan Jumlah Tenaga Kerja Yang Optimal Pada Bagian Produksi Dengan Pendekatan Metode Work Load Analysis (WLA) Di PT. Surabaya Perdana Rotopark," Journal Teknik Industri, vol. 11, no. 1, 2010.

[11] S. Wignjosoebroto, Pengantar Teknik dan Manajemen Industri. Surabaya: Guna Widya, 2003.

[12] K. Roidelindho, "Penentuan Beban Kerja Dan Jumlah Tenaga Kerja Optimal Pada Produksi Tahu," Jurnal Rekayasa Sistem Industri, vol. 3, no. 1, pp. 73-80, 2017 